\title{
A human keratin 14 "knockout": the absence of K14 leads to severe epidermolysis bullosa simplex and a function for an intermediate filament protein
}

\author{
Yiu-mo Chan, ${ }^{1}$ Ingrun Anton-Lamprecht,, ${ }^{2}$ Qian-Chun Yu, ${ }^{1}$ Andreas Jäckel, ${ }^{2}$ Bernhard Zabel, ${ }^{3}$ \\ Jan-Peter Ernst, ${ }^{4}$ and Elaine Fuchs ${ }^{1,5}$ \\ ${ }^{1}$ Howard Hughes Medical Institute, Department of Molecular Genetics and Cell Biology, The University of Chicago, \\ Chicago, Illinois 60637 USA $^{2}$ Institut für Ultrastrukturforschung der Haut, Universitäts-Hautklinik, D-69115 Heidelberg, \\ Germany; ${ }^{3}$ Department of Pediatrics, University of Mainz, D-55131 Mainz, Germany; ${ }^{4}$ Department of Pediatrics, Klinikum \\ Wiesbaden, D-65119, Wiesbaden, Germany
}

Since their discovery, the function of intermediate filaments (IFs) has remained obscure. In skin, epidermal cells have extensive cytoskeletal architectures of IFs, composed of type I and type II keratin heterodimers. Clues to possible functions of these proteins have come from recent studies showing that several autosomal-dominant, blistering skin disorders are caused by defects in genes that encode epidermal keratins. These diseases all exhibit cell degeneration and keratin network perturbations in cells that express the particular mutant keratin gene. However, it is not clear from these studies whether cytolysis arises from the presence of large insoluble keratin aggregates that compromise cellular physiology or from the absence of an extensive keratin filament network, which jeopardizes mechanical integrity. We report here the analysis of an extremely rare case of severe recessive epidermolysis bullosa simplex (EBS), where the patient lacks a discernible keratin filament network in basal epidermal cells. Genetic analyses revealed a homozygous point mutation that yielded a premature termination codon in the major basal type I keratin gene and caused complete ablation of K14. The consanguineous parents were normal, each harboring one copy of the null K14 mutation. Analysis of cultured keratinocytes enabled us to document that the loss of K14 is not compensated for by the up-regulation of any other type I keratin. When taken together with the in vivo studies showing the presence of cell fragility generated from the lack of an extensive basal keratin network, these findings provide the first clear demonstration of loss of function associated with the absence of an IF protein in vivo.

[Key Words: Intermediate filaments; epidermal keratin; epidermolysis bullosa simplex; epidermolytic hyperkeratosis]

Received August 29, 1994; revised version accepted September 12, 1994.

As members of the intermediate filament (IF) superfamily, keratins are $\alpha$-helical proteins that assemble into 10nm IFs (Fuchs and Weber 1994). Keratins are divided into two sequence types that form obligatory heteropolymers. Type I keratins include K9-K20 (63-40 kD), and type II keratins encompass K1-K8 (67-53 kD) (Moll et al. 1982). Although most combinations of type I and type II keratins can copolymerize in vitro (Franke et al. 1983), keratins are often coexpressed as specific pairs in vivo (Sun et al. 1984).

The epidermis devotes the majority of its protein-synthesizing machinery to making keratins. K5 and K14 mRNAs are restricted to cells that maintain their proliferative capacity (Nelson and Sun 1983; Byrne et al.

${ }^{5}$ Corresponding author.
1994). As basal cells differentiate, they down-regulate transcription of K5/K14 and induce new sets of differentiation-specific keratins (Fuchs and Green 1980; Moll et al. 1982; Stellmach et al. 1991). Terminally differentiating keratinocytes in most body regions express $\mathrm{K} 1$ and K10 (Fuchs and Green 1980; Roop et al. 1987). K6 and $\mathrm{K} 16$ are unusual in that they are induced suprabasally during wound healing and in epidermal cells placed in culture (Sun et al. 1984; Mansbridge and Knapp 1987). The functional significance of the multiplicity of keratins has not been resolved; however, the assembly properties of keratin pairs differ as do their interactions with associated proteins.

Like other IF proteins, keratins have a central $\alpha$-helical "rod" domain (for review, see Fuchs and Weber 1994). The rod is interrupted by three short nonhelical segments, that subdivide the helix into $1 \mathrm{~A}, 1 \mathrm{~B}, 2 \mathrm{~A}$, and $2 \mathrm{~B}$ 
domains (Hanukoglu and Fuchs 1983; Conway and Parry 1988). Type I and type II keratin rods form coiled-coil heterodimers /Coulombe and Fuchs 1990; Hatzfeld and Weber 1990; Steinert 1990), 10,000-20,000 of which align in a hierarchy of lateral and end-to-end associations to form a single 10-nm filament.

Extensive mutagenesis studies have been conducted on keratins and other IF proteins (Albers and Fuchs 1987, 1989; Gill et al. 1990; Heald and McKeon 1990; Lu and Lane 1990; Raats et al. 1990; Wong and Cleveland 1990; Letai et al. 1992). Most mutations act in a dominantnegative fashion to disrupt various interactions within IFs. In a tissue such as the epidermis where IFs are abundant, these mutations have dramatic effects in vivo. Thus, transgenic mice expressing a truncated K14 gene in skin display pathological features of epidermolysis bullosa simplex (EBS) (Coulombe et al. 1991a; Vassar et al. 1991), and mice expressing a truncated K10 gene exhibit features of epidermolytic hyperkeratosis (EH) (Fuchs et al. 1992). In humans, EBS and EH are autosomal-dominant disorders involving keratin filament aggregation and cell cytolysis in either the basal (EBS) or suprabasal (EH) layers (Anton-Lamprecht 1983, 1992, 1994). The cytolysis occurs in response to mechanical stress and leads to skin blistering.

Keratin gene mutations have now been detected in DNAs from patients with EBS (K5 and K14 mutations), $\mathrm{EH}$ (K1 and K10 mutations), and palmoplantar keratoderma (PPK; K1 and K9 mutations) (Bonifas et al. 1991; Coulombe et al. 1991b; Cheng et al. 1992; Chipev et al. 1992; Lane et al. 1992; Rothnagel et al. 1992; Reis et al. 1994; Torchard et al. 1994; for review, see Fuchs 1994). The severity of the disease correlates with the degree to which these mutants perturb IF assembly in vitro /Coulombe et al. 1991b; Cheng et al. 1992; Chipev et al. 1992; Letai et al. 1993). Patients with severe blistering frequently have mutations near the ends of the $\alpha$-helical rod, regions that are especially critical to filament elongation (Letai et al. 1992). Patients with very mild blistering often have mutations in nonhelical domains, which seem to affect lateral associations (Chan et al. 1994).

Because it is known that in mice and men, dominantnegative keratin mutations lead to cell fragility, it seems that keratins may function by imparting mechanical integrity to cells. However, it is also possible that keratin aggregates alter the cellular physiology in a gain-of-function, rather than loss-of-function manner. The notion that keratins may play a role in physical resilience of cells is further questioned by recent embryonic stem cell studies showing that some K8 $-/-$ mice with an ablated simple epithelial keratin network are seemingly normal (Baribault et al. 1993).

In discovering an extremely rare case of recessive severe EBS, we have inadvertently been able to directly address the issue of function of epidermal keratin networks. The patient is one of three similar cases among a total of now 599 EB cases lamong them 160 EBS and 44 Koebner cases) investigated and diagnosed by electron microscopy in Heidelberg (Anton-Lamprecht 1983, 1992,
1994; Anton-Lamprecht and Schnyder 1974, 1982; Ernst et al. 1993). Our finding that severe EBS occurs as a consequence of K14 ablation demonstrates for the first time a loss of function associated with the absence of an IF protein.

\section{Results}

\section{Diagnosis of an EBS patient}

The patient chosen for study, referred to here as EBS P2117, was born with skin blisters on the hands and feet. Generalized bullous lesions, particularly pronounced on the extremeties and face, have continued postnatally. The patient has a predisposition to blistering upon incidental trauma, and blisters heal without scarring. These features are typical of EBS. Multiple bone abnormalities, clinically diagnosed as osteogenesis imperfecta IV, were also present, although this was not a part of the present study. Chromosomal analyses revealed a male karyotype, $46 \mathrm{XY}$, with no numeric or gross structural abnormalities. He was the first child of healthy, clinically normal consanguineous parents.

Light microscopy of semithin sections revealed subnuclear blister formation in the basal layer (Fig. 1). Intact basal keratinocytes displayed an outstanding clear appearance, and did not stain strongly with methylene blue. Typical of EBS, initial blister formation was found within basal cells, and remnants of cytoplasm remained attached to the blister floor (Fig. 1B). Also typical of EBS, suprabasal layers remained intact and were not distinguishable from control skin.
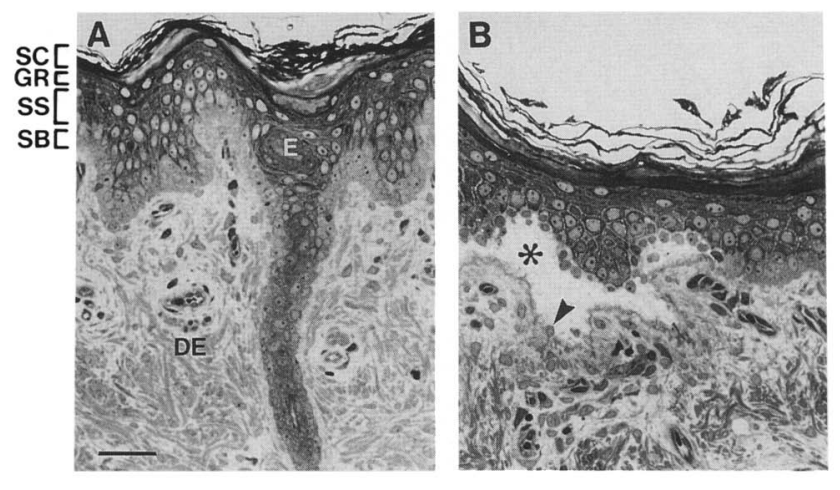

Figure 1. Morphology of skin from the EBS patient 2117. Methylene blue-stained semithin $(0.75 \mu \mathrm{m})$ sections of an EBS P2117 skin biopsy taken at 15 days of age and then embedded in Epon. (A) Intact skin showing normal epidermal architecture but a very clear basal cell layer. $(E)$ Eccrine sweat duct; (DE) dermal connective tissue (inconspicuous). (B) Blister edge of P2117 skin at 15 days. Again, basal cells of the blister region and adjacent intact skin are clear, with very little methylene blue staining. Note formation of intrabasal blister, leading to separation of the epidermis from the underlying dermis (asterisk). Note remnants of basal cell cytoplasm on the blister floor (arrowhead). Bar, $34 \mu \mathrm{m}$ in $A$ and $21 \mu \mathrm{m}$ in $B$. (DE) Dermis; (SB) stratum basale (basal layer); (SS) stratum spinosum (spinous layers); (GR) granular layer; (SC) stratum corneum. 


\section{Chan et al.}
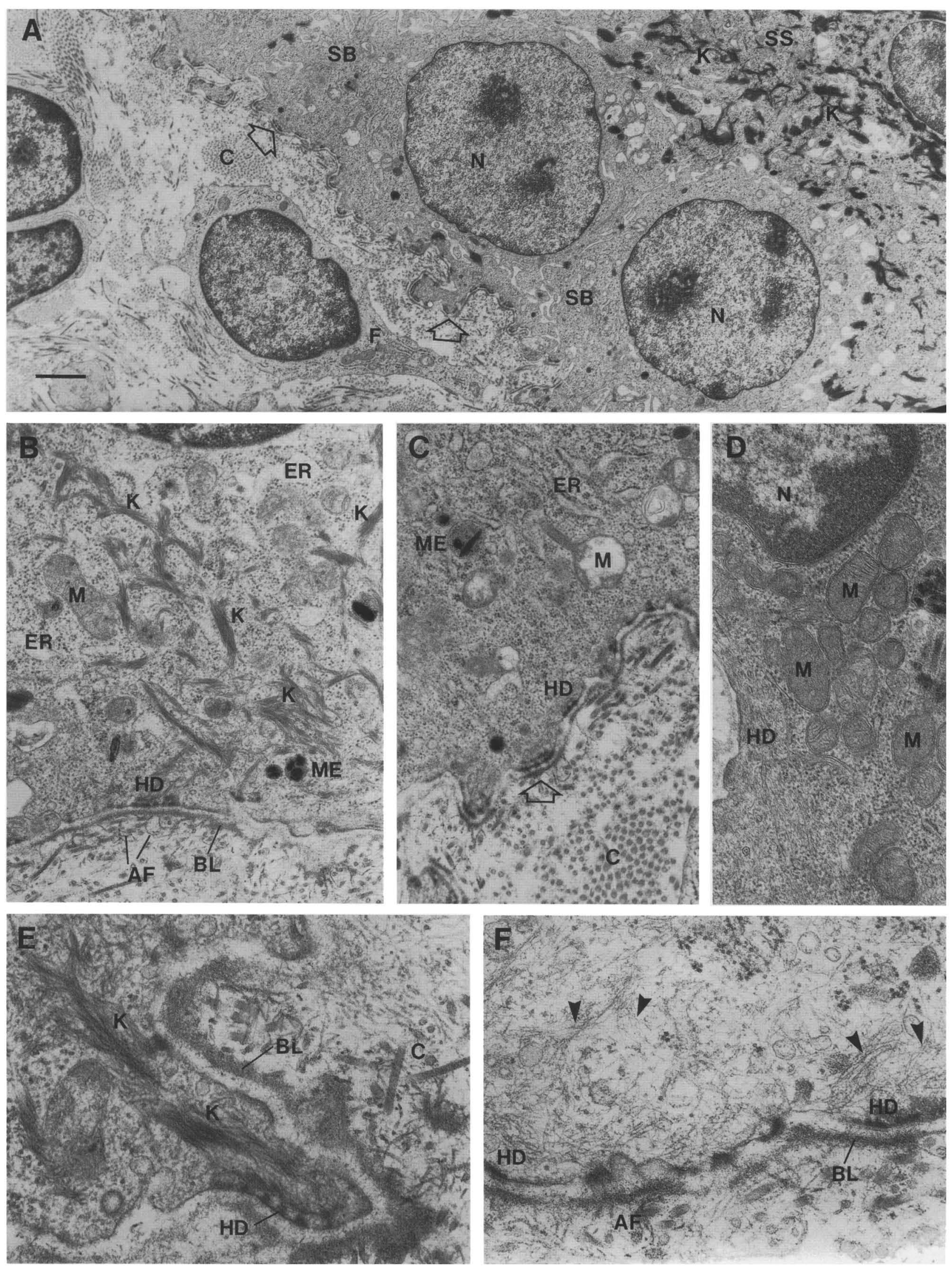

Figure 2. (See facing page for legend.) 
The ultrastructure of the EBS $P 2117$ patient reveals the absence of keratin filament bundles in the basal layer of the epidermis

Ultrastructural analyses were performed on skin samples of patient P2117 taken at 15 days and 29 months of age. In the blister edge area (not shown), all stages of initial cytolysis were encountered that were typical of intraepidermal blisters. Cytolysis started in the subnuclear cytoplasm of the basal cells. In the fully developed blister areas, intact nuclei were floating between debris of basal cell cytoplasm. The blister floor was covered by the intact dermo-epidermal junction with normal hemidesmosomes, basal lamina and anchoring fibrils, and remnants of the basal cytoplasm of epidermal cells clinging to it. These ultrastructural findings led to the diagnosis of EBS, Koebner type.

The most remarkable feature of P2117 epidermis was the complete absence of keratin filament bundles in the stratum basale, that is, basal cell layer (Fig. 2A; top open arrow points to dermoepidermal junction as well as the direction of the skin surface). In contrast, differentiating cells that had entered the first layer of the stratum spinosum (spinous layer) produced normal amounts of keratin filaments arranged in small electron dense bundles, surrounding the nuclei and inner cytoplasm in a normal fashion (Fig. 2A). All further steps of epidermal differentiation and keratinization were also normal. The marked absence of keratin filament bundles in basal cells persisted during postnatal development and was still evident at 29 months of age, when the most recent skin sample was taken (not shown). Differences in the skin at these two ages were restricted to developmental-related changes.

The absence of keratin filament bundles in the P2117 basal cell layer was strikingly different from control basal cells of skin at these ages, where small bundles of laterally aligned keratin filaments were prevalent throughout the cytoplasm (e.g., Fig. 2B,E). The trait was also distinct from autosomal-dominant EBS, where keratin filament bundles in the milder cases and aggregates or clumping of amorphous keratin in the severe cases are seen in the basal cell layer (Anton-Lamprecht 1983, 1992, 1994).
Higher magnification of P2117 basal cells revealed a normal composition and ultrastructure of all other cellular consituents except keratin filaments (Fig. 2C). Thus, Golgi bodies, endoplasmic reticulum cisternae, polyribosomes, melanin granules, and lysosomes were all indistinguishable from normal. For these structures, the only difference that we noticed between P2117 and control skin was that mitochondria seemed to cluster atypically within the cytoplasm of some basal cells (Fig. 2D). The number and structure of mitochondria were normal. Although the aberrant distribution was observed only occasionally in vivo, it was striking in vitro where the cytoplasm is largely two dimensional and organelle distribution can be clearly assessed (discussed below).

Hemidesmosomes, the major adherens junctions to the basement membrane, and desmosomes, the major intercellular adherens junctions, appeared normal in structure. However, they did not have the typical keratin filament bundles attached to them. Instead, short wispy filaments were attached to these junctions /arrowheads in F). These wispy filaments were usually concentrated at the cell periphery, and their presence seemed variable within the basal layer. They were revealed more clearly in sections embedded in unicryl as compared with Epon. They differed significantly from the keratin bundles of normal basal cells (Fig. 2E). Although they are of lower contrast than actin filaments, the wispy filaments resembled microfilaments in their loose arrangement and their peripheral localization. By conventional electron microscopy, they were difficult to identify unequivocally as keratin filaments.

\section{A premature termination codon in both alleles of $\mathrm{K} 14$}

In all prior genetic studies of severe EBS, heterozygous point mutations or small deletions were found in the coding sequences of $\mathrm{K} 14$ or $\mathrm{K} 5$ alleles (Bonifas et al. 1991; Coulombe et al. 1991b; Fuchs and Coulombe 1992; Lane et al. 1992; Chen et al. 1993; Dong et al. 1993; Humphries et al. 1993; Stephens et al. 1993). Typically, a patient with a severe case of EBS, as the first occurrence of the disease in a family, will have a spontaneous heterozygous $\mathrm{K} 5$ or $\mathrm{K} 14$ mutation at a codon especially critical for $10-\mathrm{nm}$ filament assembly.

Figure 2. The ultrastructure of $\mathrm{P} 2117$ skin is strikingly different from that of severe cases of autosomal dominant EBS. (A) Electron microscopy of skin biopsy of EBS P2117 taken at 15 days of age, fixed, and embedded in Epon. Stratum basale (SB) of intact skin shows two basal cells; portion of stratum spinosum (SS) depicts the spinous cell cytoplasm. Note complete lack of keratin filament bundles in basal cells and normal keratin filament bundles in suprabasal cells. Top open arrow points to the direction of the skin surface. (B) Subnuclear basal cell cytoplasm of a non-EBS skin control of matched age (day 21). Note normal basal cell cytoplasm with abundant keratin filament network. The hypoplasia of hemidesmosomes results from the fact that this child suffered from junctional EB, Herlitz type, a disorder involving constituents of hemidesmosomes including extracellular anchoring filaments but otherwise normal epidermis. $(C)$ Higher magnification of subnuclear basal cell cytoplasm of P2117 skin, again illustrating a normal cellular architecture but a complete absence of keratin filament bundles. $(D)$ Subnuclear portion of EBS 2117 basal cell with clustered mitochondria in keratin-free cytoplasm. Such clustering is atypical of normal basal cells but is seen in EBS P2117 basal cells occasionally in vivo and often in vitro. $(E)$ Control skin showing basal cytoplasm above dermo-epidermal junction. Note normal keratin filament bundles. $(F)$ Basal cytoplasm of EBS P2117 skin, showing loosely arranged, wispy filaments (arrowheads), often attached to hemidesmosomes. (N) Nuclei; (K) keratin filament bundles; open arrows, basal lamina; (F) dermal fibroblast; (C) collagen; (ER) endoplasmic reticulum; (M) mitochondria; (ME) melanin granules; (HD) hemidesmosome; (BL) basal lamina; (AF) anchoring fibrils. Bar, $1.4 \mu \mathrm{m}$ in $A, 0.5 \mu \mathrm{m}$ in $B$ and $C ; 0.35 \mu \mathrm{m}$ in $D ; 0.2 \mu \mathrm{m}$ in $E$ and $F$. 

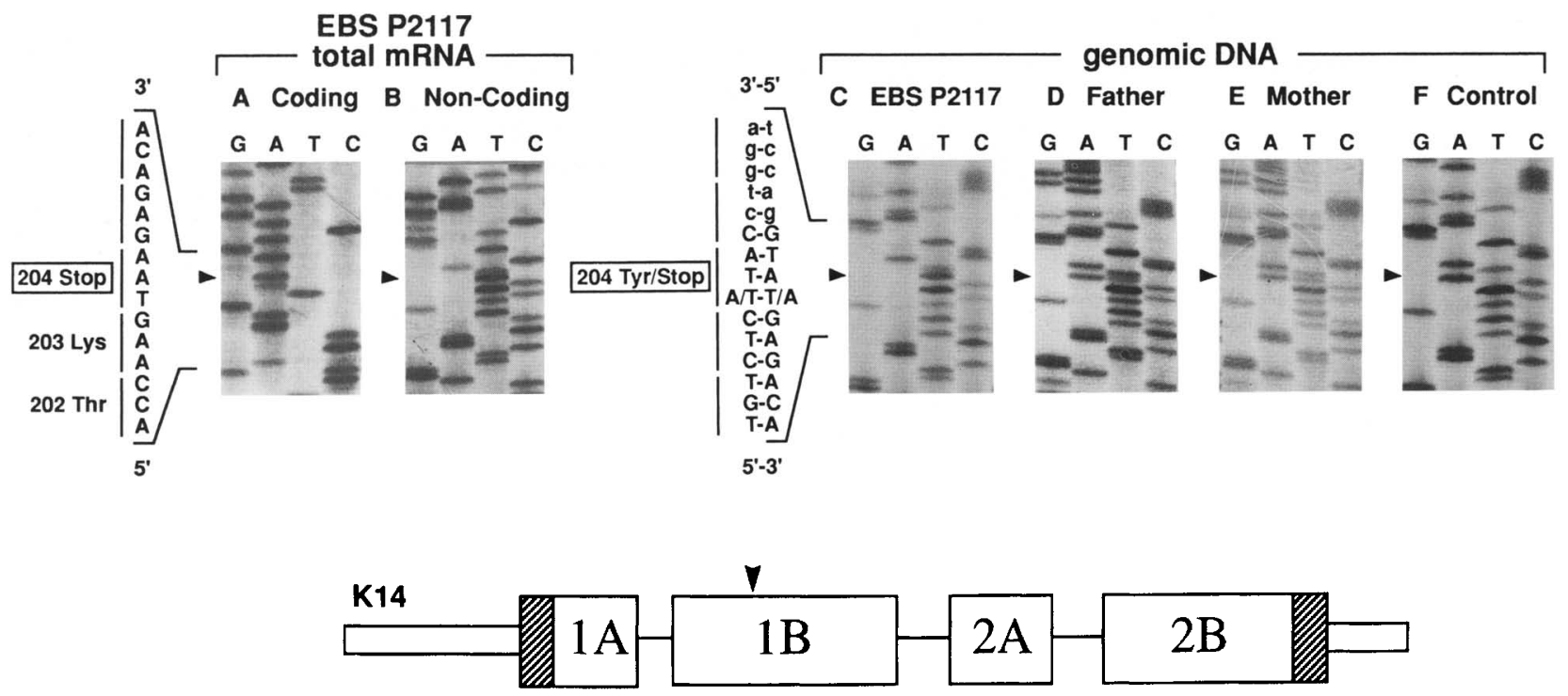

Figure 3. Sequencing of K14 from keratinocyte mRNA and genomic blood DNA of P2117 reveals a homozygous stop codon mutation early in helix 1B. $(A, B)$ Sequence of P2117 K14 cDNA. Shown are coding $(A)$ and noncoding $(B)$ strand sequences encompassing nucleotide 612, which revealed a $\mathrm{T} \rightarrow \mathrm{A}$ transversion in both alleles (arrowhead). $(C-F)$ Noncoding strand sequences of genomic $\mathrm{K} 14$ DNAs of P2117 $(C)$, father of P2117 (D), mother of P2117 (E), and a normal control $(F)$. Shown below is a diagram denoting the four $\alpha$-helical domains of the $\mathrm{K} 14$ rod (boxes). Crosshatched bars indicate highly conserved rod ends, frequently the site for mutations giving rise to severe, autosomal-dominant EBS. Arrowhead denotes the position of the homozygous premature stop codon in P2117.

The consanguineous parental history, coupled with the unusual ultrastructure of the patient's basal cells, led us to wonder whether the underlying genetic basis might be a homozygous loss of $\mathrm{K} 5$ or $\mathrm{K} 14$, a feature that might possibly be silent in the heterozygous state. To test this possibility, we isolated mRNAs from keratinocytes cultured from a skin biopsy of the EBS patient and used polymerase chain reaction (PCR) to amplify cDNAs corresponding to human $\mathrm{K} 14$ and $\mathrm{K} 5$.

Sequence analyses revealed a $\mathrm{T} \rightarrow \mathrm{A}$ transversion in the coding strand and an $\mathrm{A} \rightarrow \mathrm{T}$ transversion in the noncoding strand, each corresponding to nucleotide 612 of the K14 gene (see Marchuk et al. 1984 for sequence) (Fig. 3 , A and B, respectively|. A repeat of the PCR and sequence analyses indicated that the mutation was not an artifact of the amplification procedure. The wild-type $\mathrm{K} 14$ sequence ( $\mathrm{T}$ at codon 612 ) was not detected in the population of cDNAs amplified.

The results suggested that the mutation was homozygous and present in both of the K14 alleles of the patient. Sequence analyses of blood genomic DNA confirmed this point and revealed only an $A$ at nucleotide 612 (Fig. $3 \mathrm{Cl}$. If this homozygous mutation is responsible for the EBS phenotype, the parents should be heterozygous for the mutation, because they showed no signs of EBS. Genomic DNA of each parent contained both $A$ and $T$ at nucleotide 612 , reflective of heterozygosity $(\mathrm{D}, \mathrm{E})$. These were all in contrast to control DNAs, which showed only the wild-type $T$ nucleotide at this codon $(F)$. Intriguingly, the mutation potentially changed codon 204 from a tyrosine (TAT) to a premature termination codon (TAA) in the K14-coding sequence. No other mutations were detected in either the $\mathrm{K} 5$ or the $\mathrm{K} 14 \mathrm{cDNAs}$ of this patient.

The absence of K14 protein and a dramatic reduction in K14 mRNA in keratinocytes cultured from the EBS patient

If the homozygous premature termination mutation is real, then no wild-type $\mathrm{K} 14$ protein should be produced by the cultured EBS keratinocytes. To test this possibility, we conducted SDS-PAGE of P2117 IF proteins from cells that had been labeled for $12 \mathrm{hr}$ with $\left[{ }^{35}\right.$ S]methionine. Figure 4 shows that the $50-\mathrm{kD} \mathrm{K1} 14$ band was absent in the IF extract from the EBS keratinocytes (see Coomassie blue-stained gel and autoradiograph of $\left.{ }^{35} \mathrm{~S}\right]$ methionine-labeled keratins). Nonradioactive immunoblot analyses with a monospecific antiserum against the carboxy-terminal peptide of $\mathrm{K} 14$ was used to confirm the absence of bona fide K14.

The anti-K5 immunoblot $(\alpha \mathrm{K} 5)$ of these proteins confirmed the existence of $\mathrm{K} 5$, the $58-\mathrm{kD}$ partner to $\mathrm{K} 14$, in P2117 keratinocytes (Fig. 4). However, K5 was less abundant than in control keratinocytes (cf. lanes 1, control, and 2, EBS of Coomassie blue-stained gel and autoradiograph of $\left[{ }^{35} \mathrm{~S}\right]$ methionine-labeled keratins, respectively). Moreover, the K5 levels in P2117 cells appeared to be even lower by Coomassie staining than by radiolabeling, suggesting that the stability of K5 might be appreciably lower in these cells. These data were of interest in light of gene transfection studies showing that in foreign cells 

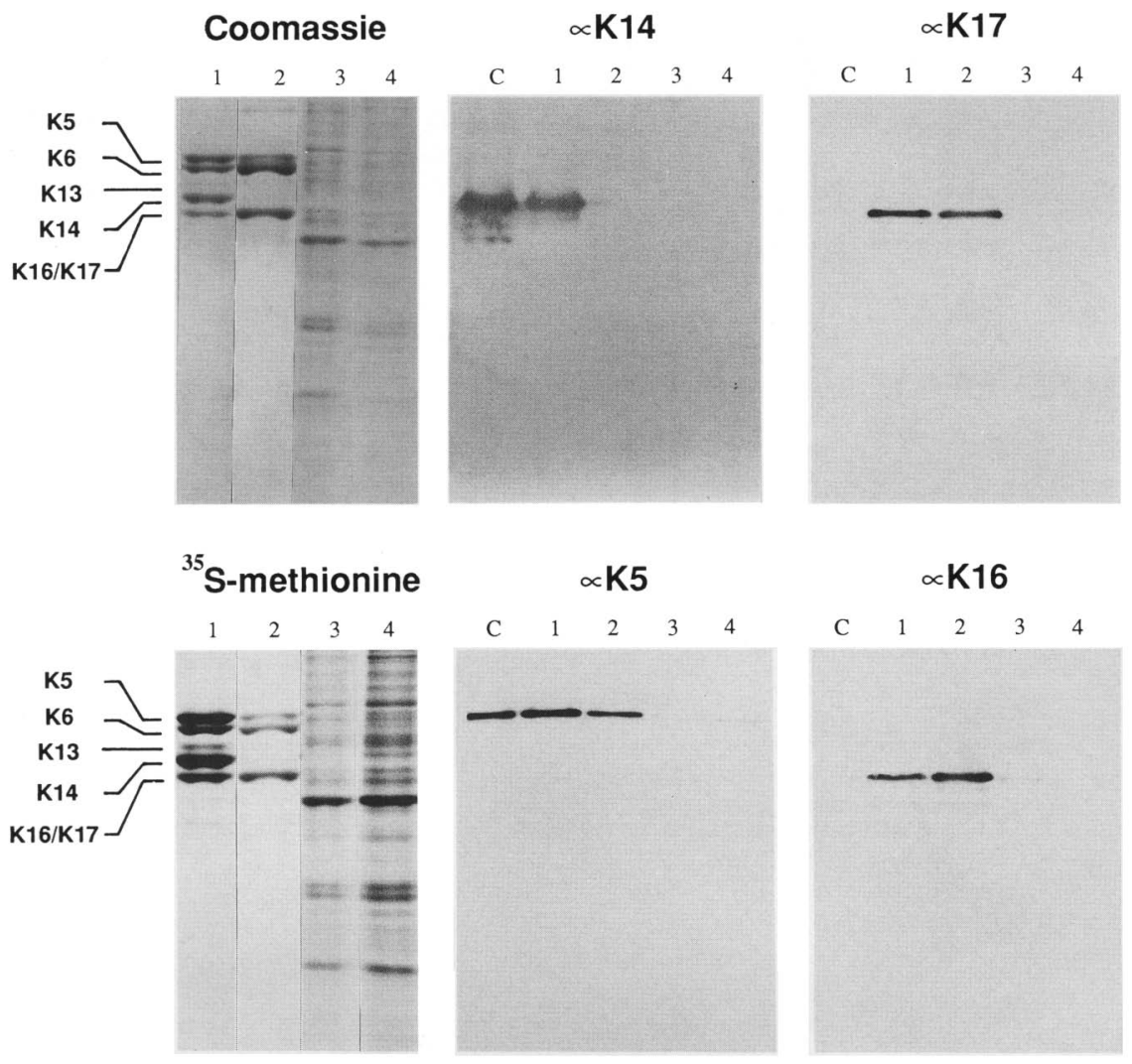

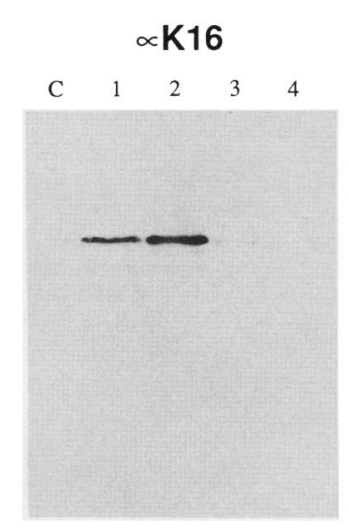

Figure 4. K14 protein is missing from P2117 keratinocytes. P2117 and control keratinocytes were radiolabeled by adding $\left[{ }^{35} \mathrm{~S}\right]$ methionine $(1 \mathrm{mCi} / \mathrm{mmole})$ at 100 $\mu \mathrm{Ci} / \mathrm{ml}$ to the culture medium $12 \mathrm{hr}$ prior to extraction. IF proteins were then isolated from these cells as described by $\mathrm{Wu}$ et al. (1982). IF proteins and Triton X-100 soluble supernatants were resolved by electrophoresis through $8.5 \%$ SDS-polyacrylamide gels and subjected to Coomassie blue staining, fluorography and autoradiography, or immunoblot analyses. Immunoblots were developed using the antibodies $\alpha \mathrm{K} 14$ (1:10,000 dilution), $\alpha \mathrm{K} 17$ (1:40,000 dilution), aK5 $\quad(1: 40,000$ dilution), or $\alpha \mathrm{K} 16$ (1:40,000 dilution), followed by horseradish peroxidase secondary antibodies and processing with a chemiluminescent substrate (ECL method; Amersham Corporation, Arlington Heights, IL). Proteins were from 1:1 molar complex between recombinant human $\mathrm{K} 5$ and $\mathrm{K} 14$ (lane $C$ ); control IF extract (lane 1); P2117 IF extract (lane 2); Triton X-100 soluble extract, control (lane 3); Triton X-100 soluble extract, P2117 (lane 4). Keratins are identified according to the nomenclature of Moll et al. (1982). Note: K6, K13, K16, and $\mathrm{K} 17$ are proteins induced in culture and not present in normal skin in vivo. lacking a type I partner, the stability of type II keratins is reduced dramatically (Kulesh and Oshima 1988; Lersch et al. 1989).

Although the difficulty in obtaining multiple skin biopsies from a severely handicapped child precluded our investigating the keratin pattern of P2117 skin, we could show that K6 (56 kD), K16 (48 kD), and K17 (48 kD), typically induced upon exposure to culture conditions, were expressed by EBS 2117 keratinocytes at levels comparable to control keratinocytes (Fig. 4). Two-dimensional gel electrophoresis using an isoelectric $\mathrm{pH}$ gradient in the first dimension was necessary to examine the minor type I epidermal keratins (Fig. 5; shown is the acidic range of the gel). These keratins were easily identified by their isoelectric $\mathrm{pH}$ and molecular sizes (Moll et al. 1982|, revealing minor amounts of $\mathrm{K} 10, \mathrm{~K} 13, \mathrm{~K} 15$, and $\mathrm{K} 19$ in control and P2117 IF extracts. Of these proteins, only $\mathrm{K} 15$ is known to be expressed in the basal layer of normal epidermis in vivo, where it is expressed at very low levels relative to K14 (Moll et al. 1982; Leube et al. 1988).

The two-dimensional gel of P2117 IF extract provided verification that the only keratin missing in the IF extract was the $\mathrm{K} 14$ protein, and overexposure of these gels revealed no unexpected spots. Collectively, these protein data indicate that the mechanisms regulating the induction and relative levels of many other cultured epidermal keratins are not dependent on or influenced by the levels of K5 and/or K14. Most importantly, the overall levels of other type I keratins did not appear to be up-regulated as a consequence of the loss of K14.

Based on the position of the premature stop codon in
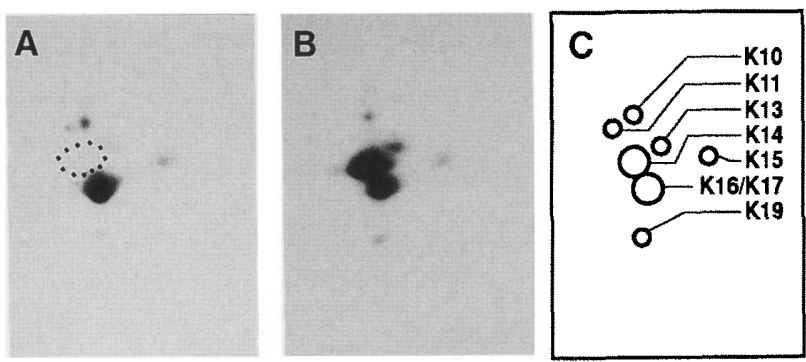

Figure 5. The absence of $\mathrm{K} 14$ is the major difference between type I keratins of P2117 and normal keratinocytes. $\left[{ }^{35}\right.$ S]Methionine-labeled IF proteins from P2117 and control keratinocytes were resolved by two-dimensional gel electrophoresis using isoelectric focusing gels in the first dimension and SDS-polyacrylamide gels in the second. After electrophoresis, gels were fixed in methanol/acetic acid solution and subjected to autoradiography. Gels were exposed to $\mathrm{x}$-ray film for 3 days. Shown is the acidic portion of the $\mathrm{pH}$ gradient $\mid \mathrm{pH} 4-5\}$. (A) P2117 IF proteins; $(B)$ control IF proteins; $(C)$ schematic, illustrating the migration of all type I keratins known to be expressed in normal epidermal cells in culture. Identification of keratins is according to Moll et al. (1982). Dotted circle denotes absence of K14 in P2117 IF extract. Note: All other type I keratin spots were present, although with the exception of $\mathrm{K} 16 / \mathrm{K} 17$, they were in minor quantities. 
Figure 6. Immunoblot scanning reveals the absence of a truncated K14 protein in $\mathrm{P} 2117$ protein extracts. To search for a possible truncated K14 protein in P2117 keratinocytes, IF and Triton $\mathrm{X}-100$ soluble extracts from P2117 and control keratinocytes were subjected to SDS-PAGE, along with a number of control proteins. Gels were electroblotted to nitrocellulose and hybridized with AE1 or anti-type I keratin antibodies, both of which cross-react with epitopes in the K14 head domain. $(A)$ Coomassie-stained gel of human K14 (lane 1); a 1:1 molar mixture of recombinant human K5 and K14 (lane 2); human vimentin (lane 3); and partially purified KVVVV, a recombinant protein containing the amino-terminal head domain of $\mathrm{K14}$ and the rest human vimentin (McCormick et al. 1991) (lane 4); Triton $\mathrm{X}-100$ soluble extract, $\mathrm{P} 2117$ (lane 5); Triton X100 soluble extract, control (lane 6); P2117 IF extract (lane7); control IF extract (lane 8). (B) (Lanes 1-8) Same loadings as above, but anti-AE 1 immunoblot; (lanes 9-12) same loadings as lanes 5-8, but anti-type I immunoblot. Mobilities of molecular mass standards (in $\mathrm{kD}$ ) are indicated at left. No cross-reacting proteins besides the full-sized type I keratins were seen or detected by these antibodies, even after gross overexposure, indicating that the $\sim 20.7-\mathrm{kD}$ truncated $\mathrm{K} 14$ protein is either not made or not stable.

the EBS K14 gene, a truncated K14 protein of $20.7 \mathrm{kD}$ might be expected to be generated (see diagram at the bottom of Fig. 3). Using immunoblot analyses, we searched the IF and Triton X-100 extracts of P2117 for a low molecular mass protein that possessed cross-reactivity with antibodies that recognize the amino-terminal head domain of K14. We found two antibodies, the mouse monoclonal AE1 (Tseng et al. 1982) and an antitype I keratin polyclonal antiserum (Fuchs and Marchuk 1983), that hybridized to a chimeric protein (McCormick et al. 1991) containing the head domain of K14 and the rod and tail domain of human vimentin (Fig. 6, lane 4). These antibodies did not react with intact human vimentin (lane 3). Thus, if a stable truncated protein were produced, it should be recognized by either of these antibodies. Although these antibodies detected all type I keratins in the IF extracts, they did not cross-react with any protein outside the range of the full-sized type I keratins (lanes 5-12). Even when gels were grossly overexposed (not shown), no lower molecular mass protein was detected by antibodies that recognized the K14 aminoterminal head domain. The inability to detect any severely truncated K14 protein in P2117 cells is in agreement with mutagenesis and gene transfection studies that we have conducted, showing that severely truncated keratins are not stable (Kouklis et al. 1994).

Given that mRNA stability is often dependent on its association with polysomes, we wondered whether the homozygous stop codon mutation might also result in reduced levels of K14 mRNA in P2117 keratinocytes. To test this possibility, we conducted Northern blot analysis on RNAs isolated from P2117 and control cultured keratinocytes (Fig. 7). Whereas the induced K6a mRNA was readily detected in the P2117 RNA sample (lane 1), the K14 mRNA was not (lane 3). Even when the blot was overexposed such that the K14 hnRNA was detectable in the control sample (lane 6), no K14 mRNA was detected in P2117 RNA (lane 5). Thus, although we were able to amplify by PCR a K14 cDNA from P2117 RNA (see Fig.

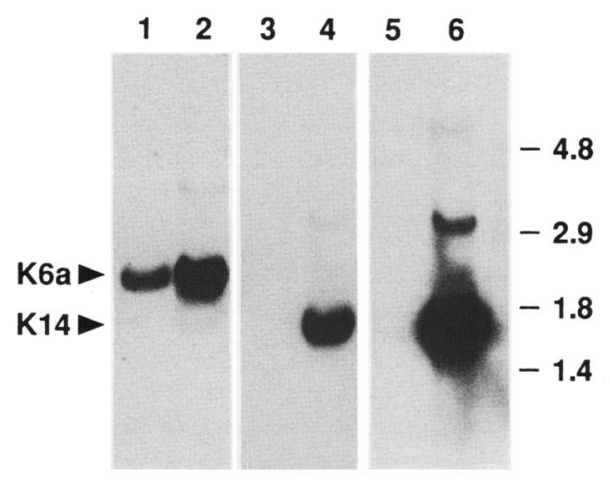

Figure 7. K14 mRNA is dramatically reduced in P2117 keratinocytes. RNAs were isolated as described previously (Albers and Fuchs 1987). P2117 RNA (7 $\mu \mathrm{g})$, and $20 \mu \mathrm{g}$ each of normal keratinocyte mRNA, 18S/28S calf liver rRNA, and 16S/23S Escherichia coli rRNA were resolved by formaldehyde gel electrophoresis and subjected to Northern blot analysis (migration of bands indicated at right in kb). First lane of each pair is P2117 RNA; second lane of each pair is control keratinocyte RNA. (Lanes 1,2) Human K6a 3' noncoding cDNA probe; (lanes 3-4) human K14 3' noncoding cDNA probe; (lanes 5-6) same as in lanes 3-4 except longer exposure to $x$-ray film to underscore that K14 mRNA in P2117 keratinocytes is grossly underrepresented. The $3.5 \mathrm{~kb}$ band in lane 6 corresponds to K14 hnRNA (Marchuk and Fuchs 1984). 
3), the level of K14 mRNA in P2117 keratinocytes was dramatically less than normal. Thus, a combination of mRNA and protein instability most likely accounts for the nondetectable levels of truncated K14 protein in P2117 cells.

The very sparse network of normal type I and type II keratins in EBS 2117 basal cells is not sufficient to impart physical resilience

To assess the possible fate of a partnerless $\mathrm{K} 5$ protein in the epidermis of the skin, we conducted immunoelectron microscopy on an EBS P2117 skin biopsy embedded in unicryl. As expected from our protein and genetic data on cultured P2117 keratinocytes, a monospecific $\alpha \mathrm{K} 14$ antiserum showed no labeling in vivo (Fig. 8A). In contrast, this antiserum significantly labeled the keratin filament bundles in control basal cells (Fig. 8B). Interestingly, although overall labeling with $\alpha \mathrm{K} 5$ antibodies was significantly less than normal, the wispy filaments seen in P2117 basal cells did label appreciably with $\alpha \mathrm{K} 5$ antibodies (Fig. 8C). The labeling was specific and was not seen over the dermis or over regions of the epidermis distinctly devoid of these filaments (e.g., the nucleus and mitochondria). In basal cells, $\alpha \mathrm{K} 5$ labeling also concentrated in the vicinity of desmosomes. In spinous layers, $\alpha \mathrm{K} 5$ labeling was largely restricted to these plaques (examples shown in Fig. 8D), whereas the large keratin filament bundles in these cells labeled normally with $\alpha \mathrm{K} 1$ and $\alpha \mathrm{K} 10$ antibodies (not shown).

The $\alpha \mathrm{K} 5$ labeling of the wispy filaments at the cell periphery of P2117 basal cells led us to anticipate that there might be a type I partner for these filaments. We first used a polyclonal antiserum that is broadly crossreactive with type I but not type II epidermal keratins (Fuchs and Marchuk 1983). As shown in Figure 8E, this antiserum specifically recognized the wispy filaments that were also labeled with $\alpha \mathrm{K} 5$. The antiserum also recognized K10-containing filaments of suprabasal P2117 cells (Fig. 8F).

The wispy filaments did not label appreciably with an antibody against $\mathrm{K} 17$, nor did they label appreciably with an $\alpha \mathrm{K} 16$ antiserum (data not shown). The most likely possibility for a type I partner to $\mathrm{K} 5$ in these cells is $\mathrm{K} 15$, known to be expressed naturally but at very low levels, in basal cells of epidermis in vivo (Moll et al. 1982; Leube et al. 1988). It is clear that the presence of this very sparse keratin network of wispy filaments was not sufficient to impart to these cells the mechanical strength necessary to withstand physical trauma.

\section{What happens when $K 6$ and $K 16$ are cosynthesized with $K 5$ in cultured P2117 keratinocytes?}

In contrast to epidermis in vivo, which has a strict downregulation of $\mathrm{K} 5$ and $\mathrm{K} 14$ concomitant with expression of either $\mathrm{Kl}$ and $\mathrm{K} 10$ (normal) or K6 and K16 (wound healing), cultured epidermal cells on plastic do not completely shut off K5 and K14 synthesis as they stratify (Tyner and Fuchs 1986). This afforded us the opportunity to examine what happens when $\mathrm{K} 6$ and $\mathrm{K} 16$ are induced in P2117 basal cells that express only K5 and not K14. This system differs from the in vivo situation where synthesis of basal and differentiation-specific keratins are mutually exclusive.

We first examined P2117 keratinocyte cultures by immunofluorescence microscopy. Figure 9 shows that some keratinocytes stained brightly with $\alpha \mathrm{K} 5$ antise rum, and as expected, these cells were negative for $\alpha \mathrm{K} 14$ staining (Fig. 9, A and B, respectively). These strongly $\alpha \mathrm{K} 5$-positive cells were larger and often suprabasal, whereas the underlying cells /denoted by arrowheads in Fig. 9A) did not stain brightly with $\alpha \mathrm{K} 5$. This was in distinct contrast to normal epidermal cultures (not shown), where the entire population stained with $\alpha \mathrm{K} 5$ and $\alpha \mathrm{K} 14$.

For suprabasal cells, the levels and appearance of $\alpha \mathrm{K} 5$ immunofluorescence were comparable for P2117 and control cultures, and these keratin networks also costained brightly with $\alpha \mathrm{K} 16$ antibodies (Fig. 9C,D). In contrast, underlying cells staining weakly with $\alpha \mathrm{K} 5$ also stained weakly with $\alpha \mathrm{K} 16$. These data suggest that the organization and stabilization of $\mathrm{K} 5$ within the cultured EBS 2117 population is dependent on its association with $\mathrm{K} 16$ (and presumably K17), which is significantly up-regulated in stratified layers of the culture (Tyner and Fuchs 1986).

Our immunofluorescence studies suggest that there are two different states of EBS 2117 keratinocytes in these cultures, one with an extensive K5-containing network, and one without an extensive keratin network at all. This was verified by embedding the cultures in Epon and subjecting them to electron and immunoelectron microscopy (Fig. 10). The two morphologically distinct types of cultured P2117 keratinocytes were interconnected by desmosomes, which were significantly fewer in number than in control cultures. Typical of normal suprabasal cells in culture, the larger P2117 cells had extensive keratin filament networks within their cytoplasm. Atypical of normal basal cells in culture, the smaller P2117 cells displayed a paucity of keratin filaments. Vast regions of the cytoplasm of these smaller keratinocytes were devoid of keratin filaments (Fig. 10A), a feature reminiscent of the cytoplasm of basal P2117 cells in vivo. P2117 basal cells in culture differed from those in vivo by the presence of some, albeit few, keratin filament bundles. These bundles were largely confined to the cell periphery and were closely associated with desmosomes.

In summary, the strongly $\alpha \mathrm{K} 5$-positive, $\alpha \mathrm{K} 14$-negative suprabasal cells detected by immunofluorescence appeared analogous to the keratin filament-packed cells seen by electron microscopy, whereas the basal cells that were barely immunofluorescent with an $\alpha \mathrm{K} 5$ antiserum seemed to be analogous to the keratin-deficient cells seen at the ultrastructural level. Immunoelectron microscopy data were consistent with this notion (not shown). Collectively, these data demonstrate that the K5 protein in EBS P2117 is fully able to participate in the assembly of typical keratin filament bundles in the ab- 


\section{Chan et al.}
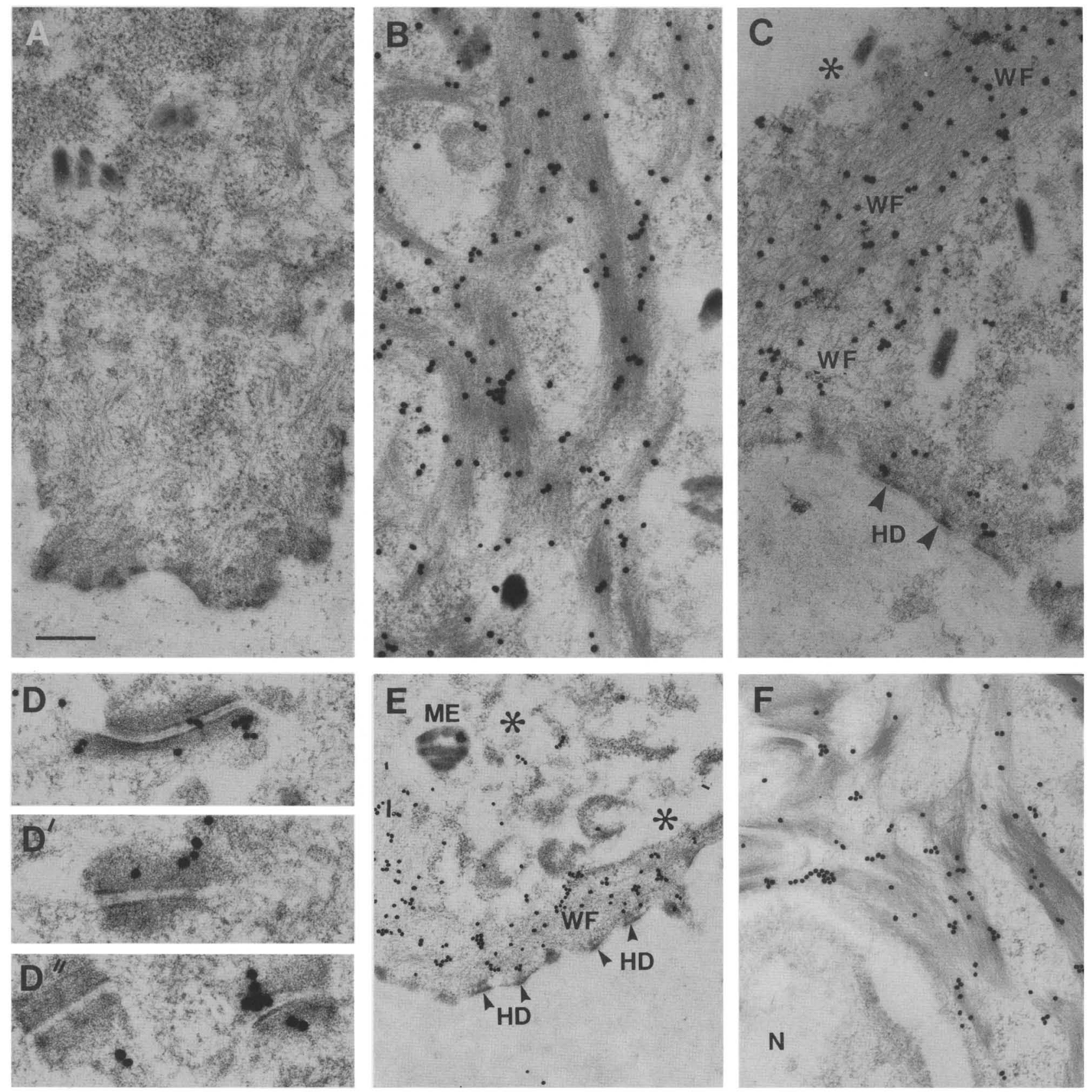

Figure 8. Immunoelectron microscopy of P2117 epidermis. Thirty-nanometer gold labeling of Unicryl embedded sections of 29month P2117 skin sample and control. (A) Anti-K14 of P2117 basal cell; note absence of any labeling. (B) Anti-K14 of control basal cell; note abundant labeling of keratin filament bundles. $(C)$, Anti-K5 of P2117 basal cell; note specific labeling of wispy filaments. $\left(D-D^{\prime \prime}\right)$ Three examples of anti-K5 labeling of electron dense material surrounding desmosomes in P2117 cells. (E) Anti-type I keratin labeling of P2117 basal cell; note labeling of wispy filaments. $(F)$ Anti-type I keratin labeling of P2117 spinous cell; note cross-reactivity of this antibody with suprabasal keratin network (K10). (WF) Wispy filaments; (arrowheads/HD) hemidesmosomes; (asterisk) cytolysis; (ME) melanin granule. Bar, $0.3 \mu \mathrm{m}$ in $A-C 0.2 \mu \mathrm{m}$ in $D ; 0.45 \mu \mathrm{m}$ in $E ; 0.4 \mu \mathrm{m}$ in $F$.

sence of its partner K14, providing that a type I epidermal keratin such as $\mathrm{K} 16$ is cosynthesized in abundance. Moreover, because in normal cultures, the small basal cells stain for $\mathrm{K} 5$ as brightly, if not more, than the suprabasal cells, these data provide compelling evidence that the levels of $\mathrm{K} 5$-containing keratin networks in cul- tured epidermal cells are dependent on the levels of type I keratin protein synthesized.

One final point that we noticed in examining our cultured P2117 keratinocytes was that the distribution of mitochondria throughout the cell cytoplasm was markedly aberrant. Often it seemed that nearly all the mito- 

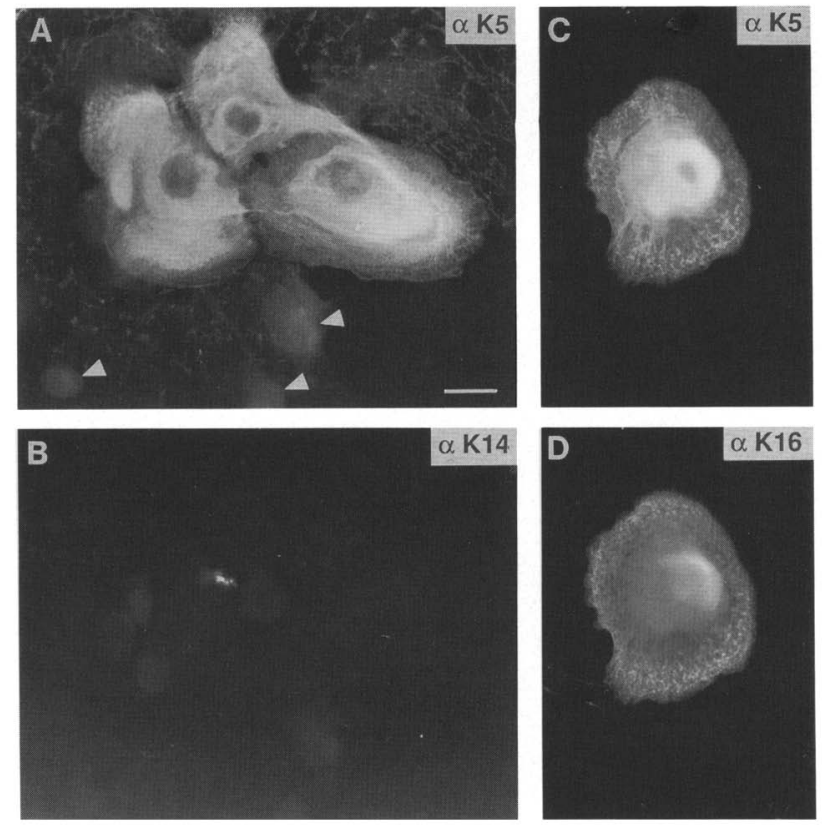

Figure 9. Immunofluorescence of cultured epidermal EBS 2117 cells reveals two distinct differentiation states. P2117 epidermal keratinocytes were cultured on coverslips, which were then subjected to double immunofluorescence with either $(A, B) \alpha \mathrm{K} 5$ and $\alpha \mathrm{K} 14 ;(C, D) \alpha \mathrm{K} 5, \alpha \mathrm{K} 16$. Note that cells underneath the three anti-K5-positive suprabasal cells in $A$ are not labeled appreciably with anti-K5 (arrowheads denote nuclei of these cells). Bar, $20 \mu \mathrm{m}$.

chondria within a cell localized to one small region of the cytoplasm (Fig. 10B), whereas other regions were notably devoid of organelles (Fig. 10A). This clustering of mitochondria, which was occasionally observed in vivo, was prominent in vitro, where keratinocytes are largely two dimensional and where ultrathin sections typically reveal abundant mitochondria. Although additional studies will be needed to fully understand this phenomenon, the observation suggests that mitochondrial distribution may be dependent on a normal IF network.

\section{Discussion}

The genetic basis of EBS patient P2117: a human K14 knockout

Our studies revealed that patient P2117 is a rare case of recessive, severe EBS attributable to a homozygous $\mathrm{T} \rightarrow$ A transversion at nucleotide 612 (codon 204) of the human K14 gene. The patient acquired these mutant K14 alleles through a consanguineous marriage of two heterozygous carriers, which are clinically normal. It is overwhelmingly likely that this mutation underlies the genetic basis for EBS in this patient, because (1) $>20$ other cases of EBS thus far have been analyzed and shown to be disorders of $\mathrm{K} 5$ or $\mathrm{K} 14$; (2) the most striking morphological abnormality of P2117 skin is the lack of keratin filament bundles in basal cells; and (3) the most striking biochemical abnormality of these cells is the complete absence of $\mathrm{K} 14$ protein and a dramatic reduction in K14 mRNA.

The mutation in P2117 generates a premature termination codon early in helix 1B. For K14 to recognize K5 efficiently in vivo, it requires at least two-thirds of either helix 1B or helix 2B (McCormick et al. 1991; M. McCormick and E. Fuchs, unpubl.). The recognition between type I and type II keratins is known to play an important role in keratin stability in vivo (Kulesh and Oshima 1988; Lersch et al. 1989). Moreover, the K14 mRNA level in these cells was grossly reduced, presumably because of the instability conferred by a lack of polysome association. When taken together, these two features most likely account for the absence of truncated K14 in the P2117 cells.

Since the inception of electron microscopy studies, perturbations in keratin filament networks have been associated with both EBS and EH phenotypes. That genetic defects in keratins might underlie these diseases was shown by demonstrating that structural aberrations of keratins in Dowling-Meara type EBS or EH keratinocytes preceded cell cytolysis (Anton-Lamprecht 1983, 1992, 1994; Anton-Lamprecht and Schnyder 1974, 1982). Transgenic technology strengthened the link between K5/K14 defects and EBS (Coulombe et al. 1991a; Vassar et al. 1991), and K1/K10 defects in EH (Fuchs et al. 1992), and genetic studies leave no doubt that the majority of EBS and EH cases have as their underlying basis autosomal dominant defects in their $\mathrm{K} 5 / \mathrm{K} 14$ (EBS) or K1/K10 (EH) alleles (Bonifas et al. 1991; Coulombe et al. 1991b; Cheng et al. 1992; Chipev et al. 1992; Lane et al. 1992; Rothnagel et al. 1992; for review, see Fuchs 1994).

The autosomal dominant nature of EBS and EH is readily understood given the dominant-negative action of genetically engineered mutant keratins (Albers and Fuchs 1987; 1989; Coulombe et al. 1990; Lu and Lane 1990; Hatzfeld and Weber 1991; Letai et al. 1992). This said, several recessive cases of EBS have been described. In one of these cases, an E144A mutation in helix 1A of K14 gives rise to very mild, localized Weber-Cockayne type EBS only when present in the homozygous state (Hovnanian et al. 1993). Patient 2117 differs from these other recessive cases in the severity of blistering. In this case, the mutation does not appear to act by interfering with keratin filament assembly, but rather is silent in the heterozygous state, presumably because sufficient quantities of $\mathrm{K} 14$ are generated from a single wild-type allele to compensate for the loss of stable expression from the mutant allele. Hence, it is only in the homozygous state that complete loss of K14 expression occurs and a normal keratin network is not produced.

The knowledge that ablation of K14 leads to severe and generalized EBS indicates that the absence of a K5 and K14 network can compromise several physiological functions. One such function is to impart mechanical stability to a cell subjected to physical stress. This natural human K14 knockout allows us to conclude that it is the absence of the K5/K14 network and not the insoluble aggregates of keratin protein that lead to cell fragility in classical, that is, autosomal-dominant, cases of EBS, and presumably EH. Is the loss of a K5/K14 network 

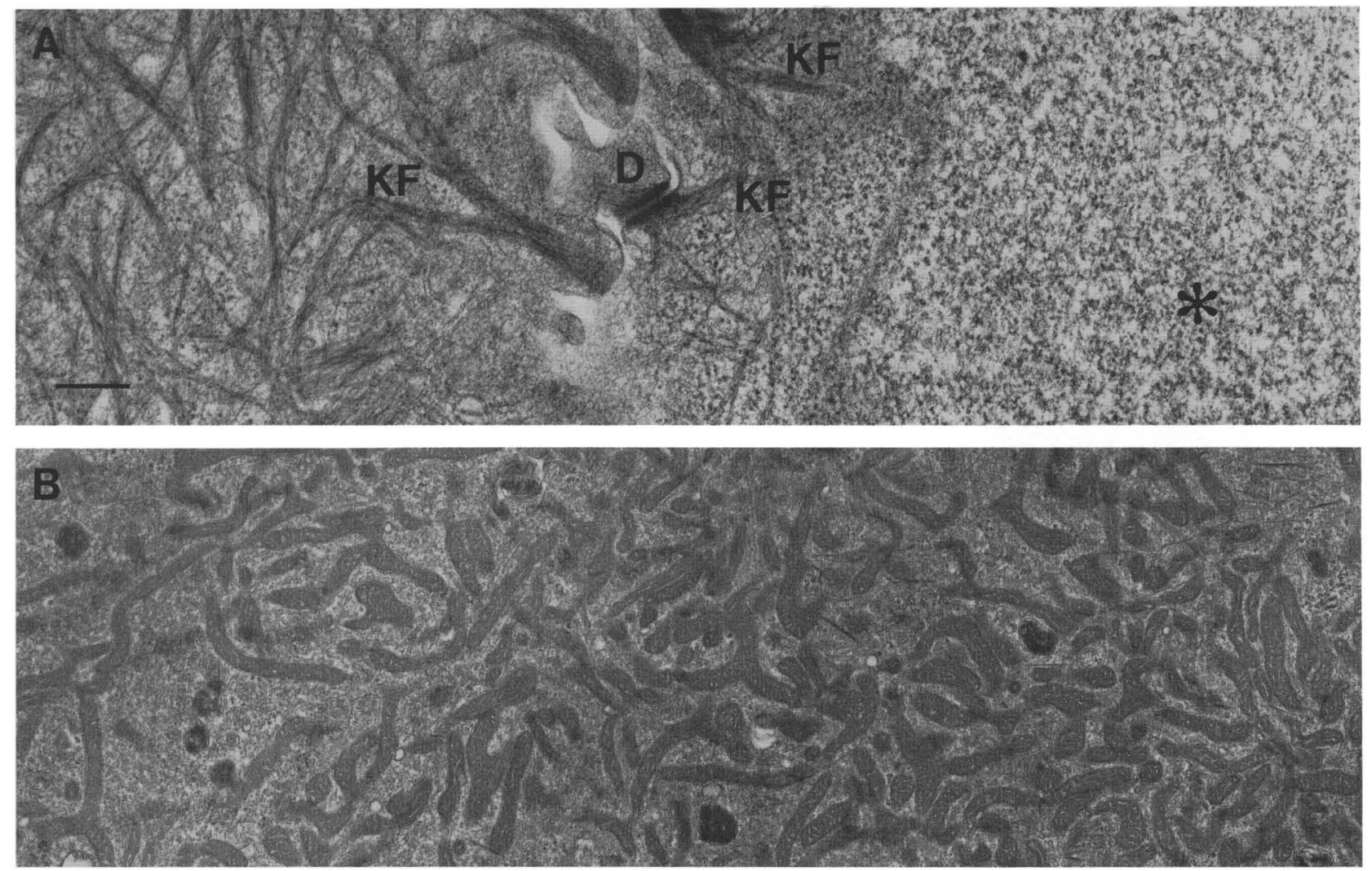

Figure 10. Electron microscopy of cultured epidermal EBS 2117 cells reveals paucity of keratin filaments in small basal cells and aberrancies in mitochondrial distribution. Cultured epidermal cells from P2117 skin were embedded in Epon and sectioned horizontally to the plane of the dish. $(A)$ Cell at left is typical of suprabasal cells in the population; cell at right is typical of basal cells in the population. (D) Desmosome; (KF) keratin filament bundles. Note paucity of keratin filaments in basal-like cell. $(B)$ Basal cell showing clustering of mitochondria. Approximately three times the number of mitochondria shown here were present in the cluster. Bar, 0.3 $\mu \mathrm{m}$ in $A$ and $1.1 \mu \mathrm{m}$ in $B$.

as deleterious to a basal cell as the presence of a disrupted K5/K14 network? Given that we have only analyzed one patient with an ablated basal keratin network, and that the influence of genetic background on keratin mutations has not yet been explored, it is difficult to say. However, the fact that this child has severe generalized EBS is indicative that at least in epidermis, IFs do have a function that cannot be compensated for by other cellular components. Moreover, while K5 does participate with an as yet unidentified type I partner (likely K15) in making a scant IF network in basal cells, this network is not sufficient to compensate for the loss of the substantially more robust K5/K14 network.

We were intrigued by the tendency of P2117 cultured epidermal cells to cluster mitochondria in the cytoplasm. We noticed this in our previous studies with severe autosomal-dominant EBS (P.A. Coulombe and E. Fuchs, unpubl.), but thought that this might be attributble to the presence of keratin aggregates, which might force the mitochondria to certain regions of the cytoplasm and exclude them from others. Our findings with cultured P2117 keratinocytes suggest that it is rather the absence of the keratin network that leads to abnormalities in mitochondrial distribution. Whereas further exploration was outside the scope of our present study, this observation is particularly fascinating in light of the recently characterized $m d m 1$ mutant in Saccharomyces cerevisiae, where a point substitution in an IF-related protein leads to abnormalities in mitochondrial and nuclear distribution (McConnell and Yaffe 1992). The potentially interesting parallels between our results and the yeast studies mandate further investigation.

\section{Differences in the behavior of partnerless $K 5$ in vivo and in vitro}

The ability of partnerless $\mathrm{K} 5$ to assemble into a normal keratin filament network was assessed from our culture studies. Although K5 is expressed in basal and suprabasal cultured cells, only suprabasal cells coexpressing K16 with $\mathrm{K} 5$ formed abundant $\mathrm{K} 5$-containing filament networks. When taken together with our in vivo data, this suggests that the level of $\mathrm{K} 5$ protein is determined by the corresponding level of type I protein in the epidermal cell, that is, it is determined by how much type I protein is present to stabilize synthesized K5. Thus, in P2117 cultures, much of the detectable K5 comes from those suprabasal cells that also make abundant $\mathrm{K} 16$ and K17, whereas the basal cells, having significantly fewer type I 
keratins in the absence of $\mathrm{K} 14$, stabilize very little $\mathrm{K} 5$. Although we were unable to quantitate the levels of K5 in P2117 cells in vivo, immunoelectron microscopy suggests that the overall level of $\mathrm{K} 5$ relative to normal basal epidermal cells is very low. Here, we expect that this low amount of $\mathrm{K} 5$ is determined by the presence of small amounts of presumably $\mathrm{K} 15$, leading to an extremely sparse network, barely discernible even at the ultrastructural level. In all cases, we found no evidence that the filament structure in K5-positive and K14-negative cells is abnormal; the filaments merely appeared to vary markedly in number, depending on the level of type I protein available for partnership.

Finally, our results address several previously unresolved and key issues of keratin filament assembly and gene regulation. Our in vivo studies indicate that normal $\mathrm{K} 1$ and $\mathrm{K} 10$ filament networks can assemble in P2117 suprabasal cells. This demonstrates that the formation of a K1 and K10 network is not dependent on a foundation of $\mathrm{K} 5$ and $\mathrm{K} 14$ filaments, as has been suggested by Kartasova et al. (1993) from their gene transfection studies in vitro. Additionally, our results indicate that with the exception of the ability of a partnerless keratin to be stabilized by the presence of a keratin of opposite type, the regulation of overall programs of keratin gene expression is not affected by aberrations in the expression of one of the keratins. The absence of K14 did not appear to stimulate any compensatory mechanisms to up-regulate expression of any other type I keratins.

\section{Summary}

In closing, by analyzing a rare recessive case of severe EBS, we were able to identify the equivalent of a human K14 knockout. This has allowed us to demonstrate for the first time that there is at least one and possibly other functions that involve epidermal keratin networks. Mechanical integrity is compromised in the $\mathrm{K} 14-/$ - basal epidermal cells and is not compensated for by the sparse K5-containing IFs that remain in these cells. The major function, namely the ability to confer physical resilience to basal cells, is vital to the proper functioning of the epidermis. In the future, it will be of interest to see whether these functions will be vital to other tissues of the body.

\section{Materials and methods}

\section{Ultrastructural analyses and culturing of skin biopsies}

Two skin samples were obtained by knife incision biopsy from intact and lesional skin from the trunk and limb of EBS patient 2117 under local anesthesia after informed consent of the parents. The first biopsy, performed at 15 days of age, was used for diagnostic electron microscopy. The second biopsy, performed at 29 months of age, was subdivided and used for culture of primary keratinocytes (Rheinwald and Green 1975) and for immunoelectron microscopy. The first biopsy was fixed immediately in $3 \%$ glutaraldehyde in $0.1 \mathrm{M}$ cacodylate buffer at $\mathrm{pH} 7.4$, partially oxidized with $\mathrm{H}_{2} \mathrm{O}_{2}$ as described previously (AntonLamprecht 1992), followed by the same fixation without $\mathrm{H}_{2} \mathrm{O}_{2}$, both at room temperature. Postfixation was performed using
$1 \%$ osmic acid, dehydration, and embedding in epoxy resin (Epon 812, now termed glycidether 100). Semithin sections were stained with methylene blue, and ultrathin sections on copper grids were treated with uranyl acetate and lead citrate.

For immunoelectron microscopy (postembedding technique), tissue was fixed in $0.1 \%$ glutaraldehyde, $0.2 \%$ picric acid in 0.1 $\mathrm{M}$ phosphate buffer solution at $\mathrm{pH}$ 7.4. Tissue was embedded in either LR-White (Science Services, Munich, Germany) at room temperature, with polymerization at $50^{\circ} \mathrm{C}$, or in Unicryl (Bio Cell, Biogenzia Lemania, Bochum, Germany) at $-20^{\circ} \mathrm{C}$. Semithin sections were subjected to immunohistochemistry using a silver staining enhancement kit (Plano Corporation, Marburg, Germany) and counterstained with methylene blue. Immunogold labeling of ultrathin sections was performed using the following antibodies: rabbit anti-human K14 (1:100 dilution; Stoler et al. 1988), rabbit anti-human K1 antisera (1:100; Stoler et al. 1988), guinea pig anti-human K5 (1:20; Lersch et al. 1989), anti-type I keratin antiserum (1:100; Fuchs and Marchuk 1983), mouse monoclonal anti-human K17 antibodies $11: 20$; Boehringer Mannheim, Indianapolis, IN), anti-actin (1:20; Amersham Corporation, Arlington Hts., IL), rabbit anti-human K16 1:100; gift of Dr. Pierre Coulombe, Johns Hopkins University, Baltimore, MD), mouse anti-K5/6, clone D5/16 B4 (1:10; Boehringer Mannheim, Germanyl, mouse anti-human K10, clone DE-K10 (1:100; Dako, Glostrup, Denmark). Antibodies were followed by protein A-conjugated $30 \mathrm{nM}$ colloidal gold or $10 \mathrm{nM}$ goat IgG immunogold antibodies as described previously (Coulombe et al. 1989; Weidenthaler et al. 1993). Prepared grids were counterstained briefly with lead citrate or with uranyl acetate and lead citrate and examined in either a JEOL-CX electron microscope (University of Chicago), or an EM 400 Philips electron microscope (Heidelberg).

\section{K5/K14 sequence analysis}

Blood samples (15-20 ml) were taken for isolation of genomic DNA. Blood samples from the unaffected parents and from $>100$ unaffected individuals were used as DNA controls. RNAs were isolated from cultured keratinocytes (Chomczynski and Sacchi 1987) and treated with RNase-free DNase (Boehringer Mannheim, Indianapolis, IN). Total mRNA was then primed with random hexamers and reverse transcribed into cDNA as described in Coulombe et al. (1991b). Reactions were used directly for PCR amplification.

PCR amplification on CDNA or genomic DNA was directly subcloned into a PCR2 vector (Invitrogen, San Diego, CA). Primers specific for the K5 (Lersch et al. 1989; Chan et al. 1993) or the K14 (Marchuk et al. 1984) genes were chosen from the published sequences. Pools of five to seven independently isolated plasmid clones were sequenced and subjected to electrophoresis through $6 \%$ polyacrylamide gels.

\section{Acknowledgments}

A very special thank you goes to Elizabeth Hutton for her expert assistance in the two-dimensional gel analyses and for her assistance in art work, and to Andrew Syder for his willingness to assist in art work above and beyond the call of duty. We are also thankful to Birgit Kandt for her expert phototechnical assistance during this study. In addition, we thank Dr. Pierre Coulombe for his gift of antibodies against human K16. This work was supported by grants from the Howard Hughes Medical Institute and from the National Institutes of Health (AR27883).

The publication costs of this article were defrayed in part by payment of page charges. This article must therefore be hereby marked "advertisement" in accordance with 18 USC section 1734 solely to indicate this fact. 


\section{References}

Albers, K. and E. Fuchs. 1987. The expression of mutant epidermal keratin cDNAs transfected in simple epithelial and squamous cell carcinoma lines. $J$. Cell Biol. 105: 791-806.

1989. Expression of mutant keratin cDNAs in epithelial cells reveals possible mechanisms for initiation and assembly of intermediate filaments. J. Cell Biol. 108: 1477-1493.

Anton-Lamprecht, I. 1983. Genetically induced abnormalities of epidermal differentiation and ultrastructure in ichthyoses and epidermolysis: pathogenesis, heterogeneity, fetal manifestation, and prenatal diagnosis. I. Invest. Dermatol. 81: $149 \mathrm{~s}-156 \mathrm{~s}$.

1992. The skin. In Diagnostic ultrastrucure of non-neoplastic diseases (ed. J.M. Papadimitriou, D.W. Henderson, and D.V. Spagnolo), pp. 459-550. Churchill Livingston, Edinburgh, Scotland.

- 1994. Ultrastructural identification of basic abnormalities as clues to genetic disorders of the epidermis. I. Invest. Dermatol. (Suppl.) (in press).

Anton-Lamprecht, I. and U.W. Schnyder. 1974. Ultrastructure of inborn errors of keratinization. Arch. Dermatol. Forsch. 250: 207-227.

- 1982. Epidermolysis bullosa herpetiformis DowlingMeara: report of a case and pathogenesis. Dermatology 164: 221-225.

Baribault, H., J. Price, K. Miyai, and R.G. Oshima. 1993. Midgestational lethality in mice lacking keratin 8 . Genes \& Dev. 7: 1191-1201.

Bonifas, J.M., A.L. Rothman, and E.H. Epstein. 1991. Epidermolysis bullosa simplex: Evidence in two families for keratin gene abnormalities. Science 254: 1202-1205.

Byrne, C., M. Tainsky, and E. Fuchs. 1994. Programming gene expression in developing epidermis. Development 120: 2369-2383.

Chan, Y.-M., Q.-C. Yu, J.-D. Fine, and E. Fuchs. 1993. The genetic basis of Weber-Cockayne epidermolysis bullosa simplex. Proc. Natl. Acad. Sci. 90: 7414-7418.

Chan, Y.-M., Q.-C. Yu, A. Christiano, J. Uitto, R.S. Kucherlapati, J. LeBlanc-Straceski, and E. Fuchs. 1994. Mutations in the non-helical linker segment L1-2 of keratin 5 in patients with Weber-Cockayne Epidermolysis Bullosa Simplex. I. Cell Sci. 107: 765-774.

Chen, M.A., J.M. Bonifas, K. Matsumara, A. Blumenfeld, and E.H. Epstein. 1993. A novel three-nucleotide deletion in the helix $2 B$ region of keratin 14 in epidermolysis bullosa simplex. Hum. Mol. Genet. 2: 1971-1972.

Cheng, I., A.J. Syder, Q.-C. Yu, A. Letai, A.S. Paller, and E. Fuchs. 1992. The genetic basis of epidermolytic hyperkeratosis: A disorder of differentiation-specific epidermal keratin genes. Cell 70: 811-819.

Chipev, C.C., B.P. Korge, N. Markova, S.J. Bale, J.J. DiGiovanna, J.G. Compton, and P.M. Steinert. 1992. A leucine $\rightarrow$ proline mutation in the $\mathrm{Hl}$ subdomain of keratin 1 causes epidermolytic hyperkeratosis. Cell 70: 821-828.

Chomczynski, P. and N. Sacchi. 1987. Single-step method of RNA isolation by acid guanidinium thiocyanate-phenolchloroform extraction. Anal. Biochem. 162: 156-159.

Conway, J.F. and D.A.D. Parry. 1988. Intermediate filament structure: 3. Analysis of sequence homologies. Int. $/$. Biol. Macromol. 10: 79-98.

Coulombe, P. and E. Fuchs. 1990. Elucidating the early stages of keratin filament assembly. J. Cell Biol. 111: 153-169.

Coulombe, P.A., R. Kopan, and E. Fuchs. 1989. Expression of keratin K14 in the epidermis and hair follicle: insights into complex programs of differentiation. J. Cell Biol. 109: 2295-2312.
Coulombe, P., Y.-M. Chan, K. Albers, and E. Fuchs. 1990. Deletions in epidermal keratins leading to alterations in filament organization in vivo and in intermediate filament assembly in vitro. J. Cell Biol. 111: 3049-3064.

Coulombe, P.A., M.E. Hutton, R. Vassar, and E. Fuchs. 1991a. A function for keratins and a common thread among different types of epidermolysis bullosa simplex diseases. J. Cell Biol. 115: 1661-1674.

Coulombe, P.A., M.E. Hutton, A. Letai, A. Hebert, A.S. Paller, and E. Fuchs. 1991b. Point mutations in human keratin 14 genes of epidermolysis bullosa simplex patients: Genetic and functional analyses. Cell 66: 1301-1311.

Dong, W., M. Ryynanen, and J. Uitto. 1993. Identification of a leucine-to-proline mutation in the keratin 5 gene in a family with the generalized kobner type of epidermolysis bullosa simplex (EBS). Hum. Mutat. 2: 94-102.

Ernst, J.-P., I. Anton-Lamprecht, B. Zabel, M. Albani, and Wiesbaden. 1993. Koinzidenz von Osteogenesis imperfecta und Epidermolysis bullosa hereditaria simplex. Annual Meeting of the German Society for Pediatrics, Würzburg, p. 32a.

Franke, W.W., D.L. Schiller, M. Hatzfeld, and S. Winter. 1983. Protein complexes of intermediate-sized filaments: melting of cytokeratin compexes in urea reveals different polypeptide separation characteristics. Proc. Natl. Acad. Sci. 80: 7113-7117.

Fuchs, E. 1994. Intermediate filaments and disease: Mutations that cripple cell strength. $J$. Cell Biol. 125: 511-516.

Fuchs, E. and P.A. Coulombe. 1992. Of mice and men: genetic skin diseases of keratin. Cell 69: 899-902.

Fuchs, E. and H. Green. 1980. Changes in keratin gene expression during terminal differentiation of the keratinocyte. Cell 19: 1033-10642.

Fuchs, E. and D. Marchuk. 1983. Type I and type II keratins have evolved from lower eukaryotes to form the epidermal intermediate filaments in mammalian skin. Proc. Natl. Acad. Sci. 80: $5857-5861$.

Fuchs, E. and K. Weber. 1994. Intermediate filaments: structure, dynamics, function, and disease. Annu. Rev. Biochem. 63: 345-382.

Fuchs, E., R.A. Esteves, and P.A. Coulombe. 1992. Transgenic mice expressing a mutant keratin 10 gene reveal the likely genetic basis for Epidermolytic Hyperkeratosis. Proc. Natl. Acad. Sci. 89: 6906-6910.

Gill, S.R., P.C. Wong, M.J. Monteiro, and D.W. Cleveland. 1990. Assembly properties of dominant and recessive mutations in the small mouse neurofilament (NF-L) subunit. J. Cell Biol. 111: 2005-2019.

Hanukoglu, I. and E. Fuchs. 1983. The cDNA sequence of a type II cytoskeletal keratin reveals constant and variable structural domains among keratins. Cell 33: 915-924.

Hatzfeld, M. and K. Weber. 1990. The coiled coil of in vitro assembled keratin filaments is a heterodimer of type I and II keratins: Use of site-specific mutagenesis and recombinant protein expression. J. Cell Biol. 110: 1199-1210.

1991. Modulation of keratin intermediate filament assembly by single amino acid exchanges in the consensus sequence at the C-terminal end of the rod domain. J. Cell Sci. 99: 351-362.

Heald, R. and F. McKeon. 1990. Mutations of phosphorylation sites in lamin $A$ that prevent nuclear lamina disassembly in mitosis. Cell 61: 579-589.

Hovnanian, A., E. Pollack, L. Hilal, A. Rochat, C. Prost, Y. Barrandon, and M. Goossens. 1993. A missense mutation in the rod domain of keratin 14 associated with recessive epidermolysis bullosa simplex. Nature Genet. 3: 327-332.

Humphries, M.M., D.M. Sheils, G.J. Farrar, R. Kumar-Singh, P.F. Kenna, F.C. Mansergh, S.A. Jordan, M. Young, and P. 
Humphries. 1993. A mutation (Met $\rightarrow$ Arg) in the type I keratin (K14) gene responsible for autosomal dominant epidermolysis bullosa simplex. Hum. Mutat. 2: 37-42.

Kartasova, T., D.R. Roop, K.A. Holbrook, and S.H. Yuspa. 1993. Mouse differentiation-specific keratins 1 and 10 require a preexisting keratin scaffold to form a filament network. $I$. Cell Biol. 120: 1251-1261.

Kouklis, P., E. Hutton, and E. Fuchs. 1994. Making the connection: keratin intermediate filaments and desmosomes. $J$. Cell Biol. (in press).

Kulesh, D.A. and R.G. Oshima. 1988. Cloning of the human keratin 18 gene and its expression in nonepithelial mouse cells. Mol. Cell. Biol. 8: 1540-1550.

Lane, E.B., E.L. Rugg, H. Navsaria, I.M. Leigh, A.H.M. Heagerty, A. Ishida-Yamamoto, and R.A.J. Eady. 1992. A mutation in the conserved helix termination peptide of keratin 5 in hereditary skin blistering. Nature 356: 244-246.

Lersch, R., V. Stellmach, C. Stocks, G. Giudice, and E. Fuchs. 1989. Isolation, sequence, and expression of a human keratin K5 gene: transcriptional regulation of keratins and insights into pairwise control. Mol. Cell. Biol. 9: 3685-3697.

Letai, A., P. Coulombe, and E. Fuchs. 1992. Do the ends justify the mean? Proline mutations at the ends of the keratin coiled-coil rod segment are more disruptive than internal mutations. I. Cell Biol. 116: 1181-1195.

Letai, A., P.A. Coulombe, M.B. McCormick, Q.-C. Yu, E. Hutton, and E. Fuchs. 1993. Disease severity correlates with position of keratin point mutations in patients with epidermolysis bullosa simplex. Proc. Natl. Acad. Sci. 90: 31973201.

Leube, R.E., B.L. Bader, F.X. Bosch, R. Zimbelmann, T. Achtstaetter, and W.W. Franke. 1988. Molecular characterization and expression of the stratification-related cytokeratin 4 and 15. J. Cell Biol. 106: 1249-1261.

Lu, X. and E.B. Lane. 1990. Retrovirus-mediated transgenic keratin expression in cultured fibroblasts: Specific domain functions in keratin stabilization and filament formation. Cell 62: 681-696.

Mansbridge, J.N. and A.M. Knapp. 1987. Changes in keratinocyte maturation during wound healing. I. Invest. Dermatol. 89: 253-262.

Marchuk, D., S. McCrohon, and E. Fuchs. 1984. Remarkable conservation of structure among intermediate filament genes. Cell 39: 491-498.

McConnell, S.J. and M.P. Yaffe. 1992. Nuclear and mitochondrial inheritance in yeast depends on novel cytoplasmic structures defined by the MDM1 protein. I. Cell Biol. 118: 385-395.

McCormick, M.B., P. Coulombe, and E. Fuchs. 1991. Sorting out IF networks: consequences of domain swapping on IF recognition and assembly. J. Cell Biol. 113: 1111-1124.

Moll, R., W.W. Franke, D.L. Schiller, B. Geiger, and R. Krepler. 1982. The catalog of human cytokeratins: Patterns of expression in normal epithelia, tumors, and cultured cells. Cell 31: 11-24.

Nelson, W. and T.-T. Sun. 1983. The 50- and 58-kdalton keratin classes as molecular markers for stratified squamous epithelia: Cell culture studies. I. Cell Biol. 97: 244-251.

Raats, J.M.H., F.R. Pieper, W.T.M. Vree Egberts, K.N. Verrijp, F.C.S. Ramaekers, and H. Bloemendal. 1990. Assembly of amino terminally deleted desmin in vimentin-free cells. $J$. Cell Biol. 111: 1971-1985.

Raats, J.M.H., J.B.J. Henderik, M. Verdijk, F.L.G. van Oort, W.L.H. Gerards, F.C.S. Ramaekers, and H. Bloemendal. 1991. Assembly of carboxy-terminally deleted desmin in vimentin-free cells. Eur. J. Cell Biol. 56: 84-103.
Reis, A., H.C. Hennies, L. Langbein, M. Digweed, D. Mischke, M. Drechsler, E. Schrock, B. Royer-Pokora, W. Franke, K. Sperling, and W. Kuster. 1994. Keratin 9 gene mutations in epidermolytic palmoplantar keratoderma (EPPK). Nature Genet. 6: 174-179.

Rheinwald, J.G. and H. Green. 1975. Serial cultivation of strains of human epidermal keratinocytes: the formation of keratinizing colonies from single cells. Cell 6: 331-343.

Roop, D.R., H. Huitfeldt, A. Kilkenny, and S.H. Yuspa. 1987. Regulated expression of differentiation-associated keratins in cultured epidermal cells detected by monospecific antibodies to unique peptides of mouse epidermal keratins. Differentiation 35: 143-150.

Rothnagel, J.A., A.M. Dominey, L.D. Dempsey, M.A. Longley, D.A. Greenhalgh, T.A. Gagne, M. Huber, E. Frenk, D. Hohl, and D.R. Roop. 1992. Mutations in the rod domains of keratins 1 and 10 in epidermolytic hyperkeratosis. Science 257: 1128-1130.

Steinert, P.M. 1990. The two-chain coiled-coil molecular of native epidermal keratin intermediate filaments is a type I-type II heterodimer. J. Biol. Chem. 265: 8766-8774.

Stellmach, V., A. Leask, and E. Fuchs. 1991. Retinoid-mediated transcriptional regulation of keratin genes in human epidermal and squamous cell carcinoma cells. Proc. Natl. Acad. Sci. 88: 4582-4586.

Stephens, K., V.P. Sybert, E.M. Wijsman, P. Ehrlich, and A. Spencer. 1993. A keratin 14 mutational hot spot for epidermolysis bullosa simplex, Dowling-Meara: implications for diagnosis. J. Invest. Dermatol. 101: 240-243.

Stoler, A., R. Kopan, M. Duvic, and E. Fuchs. 1988. The use of monospecific antibodies and cRNA probes reveals abnormal pathways of terminal differentiation in human epidermal diseases. I. Cell Biol. 107: 427-446.

Sun, T.-T., R. Eichner, A. Schermer, D. Cooper, W.G. Nelson, and R.A. Weiss. 1984. The transformed phenotype. In The cancer cell led. A. Levine, W. Topp, G. vande Woude, and J.D. Watson), vol. 1, pp. 169-176. Cold Spring Harbor Laboratory, Cold Spring Harbor, New York).

Torchard, D., C. Blanchet-Bardon, O. Serova, L. Langbein, S. Narod, N. Janin, A.F. Goguel, A. Bernheim, W.W. Franke, G.M. Lenoir, and J. Feunteun. 1994. Epidermolytic palmoplantar keratoderma cosegregates with a keratin 9 mutation in a pedigree with breast and ovarian cancer. Nature Genet. 6: 106-109.

Tseng, S.C.G., M.J. Jarvinen, W.G. Nelson, J.-W. Huang, J. Woodcock-Mitchell, and T.-T. Sun, 1982. Correlation of specific keratins with different types of epithelial differentiation: Monoclonal antibody studies. Cell 30: 361-372.

Tyner, A.L. and E. Fuchs. 1986. Evidence for posttranscriptional regulation of the keratins expressed during hyperprolifera. tion and malignant transformation in human epidermis. $J$. Cell Biol. 103: 1945-1955.

Vassar, R., P.A. Coulombe, L. Degenstein, K. Albers, and E. Fuchs. 1991. Mutant keratin expression in transgenic mice causes marked abnormalities resembling a human genetic skin disease. Cell 64: 365-380.

Weidenthaler, B., I. Hauber, and I. Anton-Lamprecht. 1993. Is filaggrin really a filament-aggregating protein in vivo? Arch. Dermatol. Res. 285: 111-120.

Wong, P.C. and D.W. Cleveland. 1990. Characterization of dominant and recessive assembly defective mutations in mouse neurofilament NF-M. I. Cell Biol. 111: 1987-2003.

Wu, Y.-J., L.M. Parker, N.E. Binder, M.A. Beckett, J.H. Sinard, C.T. Griffiths, and J.G. Rheinwald. 1982. The mesothelial keratins: A new family of cytoskeletal proteins identified in cultured mesothelial cells. Cell 31: 693-703. 


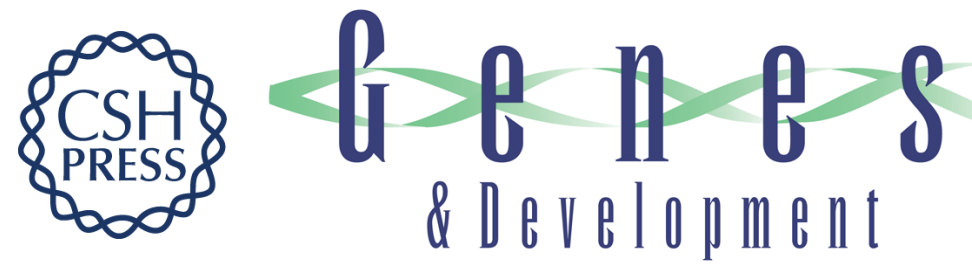

\section{A human keratin 14 "knockout": the absence of K14 leads to severe epidermolysis bullosa simplex and a function for an intermediate filament protein.}

Y Chan, I Anton-Lamprecht, Q C Yu, et al.

Genes Dev. 1994, 8:

Access the most recent version at doi:10.1101/gad.8.21.2574

References This article cites 66 articles, 34 of which can be accessed free at:

http://genesdev.cshlp.org/content/8/21/2574.full.html\#ref-list-1

License

Email Alerting Receive free email alerts when new articles cite this article - sign up in the box at the top Service right corner of the article or click here.

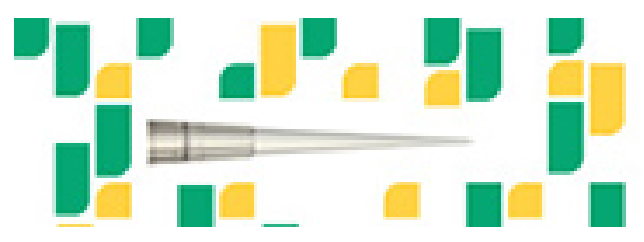

Focused on your science. 